\title{
MICROBIAL BIOMASS AND SOIL FAUNA DURING THE DECOMPOSITION OF COVER CROPS IN NO-TILLAGE SYSTEM(1)
}

\author{
Luciano Colpo Gatiboni $^{(2)}$, Jefferson Luis Meirelles Coimbra ${ }^{(2)}$, \\ Rosiane Berenice Nicoloso Denardin ${ }^{(3)} \&$ Leandro do Prado \\ Wildner ${ }^{(4)}$
}

\begin{abstract}
SUMMARY
The decomposition of plant residues is a biological process mediated by soil fauna, but few studies have been done evaluating its dynamics in time during the process of disappearance of straw. This study was carried out in Chapecó, in southern Brazil, with the objective of monitoring modifications in soil fauna populations and the $C$ content in the soil microbial biomass $\left(\mathrm{C}_{\mathrm{SMB}}\right)$ during the decomposition of winter cover crop residues in a no-till system. The following treatments were tested: 1) Black oat straw (Avena strigosa Schreb.); 2) Rye straw (Secale cereale L.); 3) Common vetch straw (Vicia sativa $\mathrm{L}$.). The cover crops were grown until full flowering and then cut mechanically with a rolling stalk chopper. The soil fauna and $\mathrm{C}$ content in soil microbial biomass $\left(\mathrm{C}_{\mathrm{SMB}}\right)$ were assessed during the period of straw decomposition, from October 2006 to February 2007. To evaluate $\mathrm{C}_{\mathrm{SMB}}$ by the irradiation-extraction method, soil samples from the 0-10 cm layer were used, collected on eight dates, from before until 100 days after residue chopping. The soil fauna was collected with pitfall traps on seven dates up to 85 days after residue chopping. The phytomass decomposition of common vetch was faster than of black oat and rye residues. The $\mathrm{C}_{\mathrm{SMB}}$ decreased during the process of straw decomposition, fastest in the treatment with common vetch. In the common vetch treatment, the diversity of the soil fauna was reduced at the end of the decomposition process.
\end{abstract}

Index terms: microbial carbon, straw decomposition, soil microorganisms, plant residues.

\footnotetext{
(1) Experiment sponsored by Santa Catarina State University and Santa Catarina State Agriculture Research Center. Received for publication in July 14, 2010 and approved in May 20, 2011.

${ }^{(2)}$ Agronomist, Professor at Santa Catarina State University, CNPq Researcher. Avenida Luis de Camões 2090, CEP 88520-000 Lages (SC), Brazil. E-mails: gatiboni@cav.udesc.br; coimbrajefferson@cav.udesc.br

(3) Agronomist, Professor at South Frontier Federal University, Chapecó, Brazil. E-mail: denardin500@gmail.com

(4) Agronomist, Researcher at Santa Catarina Agricultural Research Center, Chapecó, Brazil. E-mail: lpwild@epagri.sc.gov.br
} 


\title{
RESUMO: BIOMASSA MICROBIANA E FAUNA DO SOLO DURANTE A DECOMPOSICTÃO DE PLANTAS DE COBERTURA EM SISTEMA PLANTIO DIRETO
}

\begin{abstract}
A decomposição de resíduos é um processo biológico mediado pela fauna do solo, mas poucos estudos foram feitos avaliando sua dinâmica temporal durante o processo de decomposição da palhada. O presente trabalho foi realizado na cidade de Chapecó, região Sul do Brasil, com o objetivo de monitorar as modificações populacionais da fauna do solo e do conteúdo de $C$ armazenado na biomassa microbiana do solo durante a decomposição de plantas de cobertura de inverno em sistema plantio direto. Foram testados: palhada de aveiapreta (Avena strigosa Schreb.); palhada de centeio (Secale cereale L.); e palhada de ervilhaca (Vicia sativa L.). As plantas de cobertura foram cultivadas até pleno florescimento e, depois, manejadas mecanicamente com rolo-faca. As avaliações de fauna do solo e conteúdo de $C$ armazenado na biomassa microbiana do solo $\left(C_{B M S}\right)$ foram realizadas durante o periodo de decomposição da palhada, de outubro de 2006 a fevereiro de 2007. Para avaliação do $C_{B M S}$ pelo método de irradiação-extração, foram usadas amostras de solo da camada de 0-10 cm, coletadas em oito datas, desde antes da rolagem até 100 dias depois. A fauna do solo foi coletada com armadilhas de superfície do tipo pitfall em sete datas, até 85 dias após a rolagem. A fitomassa da evilhaca foi decomposta mais rapidamente que a da aveia-preta e do centeio, e o $C_{B M S}$ decresceu durante o processo de decomposição das plantas de cobertura, sendo o decréscimo mais rápido no tratamento com ervilhaca. Quanto ao tratamento ervilhaca, houve diminuição da diversidade da fauna edáfica no final do processo de decomposição.
\end{abstract}

Termos de indexação: carbono microbiano, decomposição da palha, microrganismos do solo, resíduos culturais.

\section{INTRODUCTION}

No tillage is a widely used management system for grain crops in the southern region of Brazil (Bolliger et al., 2006). The system requires uninterrupted maintenance of the soil cover by straw residue during the fallow period, to protect the soil from the erosive effects of rain and for a gradual build-up of the soil physical, chemical and biological quality. Thus, the success of the no-tillage system depends on the time the mulch or residue remains on the soil surface, which, for its part, depends on the quantity and residue quality added and on the decomposing organisms (Bolliger et al., 2006; Anghinoni, 2007).

The residue decomposition is influenced by the organisms that inhabit and decompose the litter, among them microbial microorganisms in the biomass, such as bacteria and fungi, as well as by fauna meso- and macroorganisms, such as oligochaeta and arthropods (Stinner \& House, 1990; Lavelle et al., 1992; Lavelle, 1997). Two main carbon sources serve as energy source of the soil microbial biomass: soil organic matter and organic residues added to the soil (Brookes et al., 2008). The soil microbial biomass can survive in the soil in minimal quantities, consuming soil organic matter, and when fresh organic residues are added to the soil, there is an increase in the microbial population, increasing the $\mathrm{C}$ and $\mathrm{N}$ quantity stored in the microbial biomass, indicating the sensitivity of the microorganisms to residue addition (Wagner \& Wolf, 1998; Moreira \& Siqueira, 2006). The effect duration of the organic matter addition is variable, according to the residue quality, so that the period of increase in soil microbial biomass may last for less than 20 days for easily decomposable material up to some months for more resistant residues (Lundquist et al., 1999; Debosz et al., 1999; Rasiah \& Kay, 1999; Stark et al., 2008). However, Debosz et al. (1999) and Rutigliano et al. (2009) stated that due to the sensitivity of soil microbial biomass to environmental factors, the soil microbial biomass should be repeatedly measured to isolate the effect of the treatments from seasonal oscillations.

The decomposition process through the microbial biomass is partly based on the action of soil fauna, principally mesofauna $(0.2-2.0 \mathrm{~mm})$ and macrofauna $(>2.0 \mathrm{~mm})$, which cause the fragmentation of the plant residues, increasing the contact area for decomposition (Lavelle, 1997). Seastedt (1984) reviewed the effect of arthopods on the decomposition of organic residues and found studies that showed a reduction of up to $63 \%$ of the decomposition rate when these organisms were removed from the system. Hättenschwiler et al. (2005) stated that the direct effect of arthropods on carbon mineralization is low (around $10 \%$ ), while the indirect effect is very high, since the fragmentation of organic matter and predation by other organisms of the food chain directly affect the process of microbial residue deomposition.

Hättenschwiler et al. (2005) claimed that although soil fauna plays a relevant role in the decomposition process of organic residues, few studies have investigated soil fauna behavior during the process of residue decomposition, because the population diversity is great and the isolation of the principal factors rather difficult (Moço et al., 2005). Gatiboni et al. (2009) evaluated soil fauna during the decomposition of black oat and rye residues in a notill system and observed that the reduced availability of plant residues through decomposition caused a 
reduction in the soil fauna diversity, principally by the relative increase of collembola.

This study was conducted to evaluate modifications in soil fauna populations and the microbial biomass during the decomposition process of crop residues of oat, rye and common vetch in a no-till system.

\section{MATERIAL AND METHODS}

The experiment was conducted in the 2006/2007 growing season in the experimental area of the agriculture research center of the state of Santa Catarina (EPAGRI) in Chapecó, Santa Catarina (latitude $27^{\circ} 12$ ' 40 " South, longitude $52^{\circ} 37^{\prime} 36$ " West, $670 \mathrm{~m}$ asl). The regional climate is mesothermal humid subtropical (Cfa), according to the Köppen classification. The soil of the study area was a Red Oxisol (Embrapa, 2006) under long-term no-tillage. Cover crops were planted annually in the winter and the area left fallow during the summer.

The experiment was arranged in a completely randomized design with four replications, with three treatments: 1) black oat straw (Avena strigosa Schreb.); 2) rye straw (Secale cereale L.); 3) Common vetch straw (Vicia sativa L.). The cover crops were sown at the beginning of the winter and grown until full flowering, at the end of spring. Rye and oat were fertilized with $100 \mathrm{~kg} \mathrm{ha}^{-1} \mathrm{~N}$, divided into two applications (45 and 60 days after planting).

At full flowering, the cover crops were mechanically cut with a rolling stalk chopper and from then on, the decomposition rate of the residue was evaluated on a weekly basis by sampling the residues remaining on the soil in five subsamples of $0.25 \mathrm{~m}^{2}$ per plot. The dry matter (DM) quantity remaining on the soil was converted to $\mathrm{kg} \mathrm{ha} \mathrm{h}^{-1}$ as suggested by Singh et al. (2007). To estimate the decomposition rate, a first-order kinetic model was fit: $\mathrm{DM}_{\mathrm{t}}=\mathrm{DM}_{0}{ }^{*} \mathrm{e}^{(-k t)}$, where $\mathrm{DM}_{\mathrm{t}}=$ remaining quantity of dry matter in time $\mathrm{t} ; \mathrm{DM}_{0}=$ initial quantity of dry matter; $\mathrm{t}=$ decomposition period. The time required for decomposition of 50 and $95 \%$ of the dry matter was calculated by the expressions $t_{50}=0.693 / \mathrm{k}$ and $t_{95}=3 / \mathrm{k}$.

The soil fauna was sampled periodically during the decomposition process with the first sampling on the day before the cutting of the cover crops (-1) and at $03,19,42,54,70$ and 85 days after cutting. Soil fauna was captured in pitfall traps, which consist of $2 \mathrm{~L}$ plastic bottles (diameter $10 \mathrm{~cm}$ ) into which four rectangular orifices of $15 \mathrm{~cm}^{2}$ were drilled in the upper third of the bottle. The traps were buried so that the openings were even with the soil surface level, and filled with a preservative solution (alcohol $70 \%+$ glycerin $1 \%$ ). The traps were left in the field for $48 \mathrm{~h}$ and then taken to the soil chemistry laboratory of the Santa Catarina State University (UDESC). The collected material was washed over a $0.25 \mathrm{~mm}$ sieve and the collected organisms identified and quantified using a 40x magnifying glass. For presentation of the results of abundance of organisms, groups with a frequency of less than $1 \%$ were grouped in the class of "others". The Shannon Diversity Index $(\mathrm{H})$ of the fauna population was calculated, using the Bio-Dap software, and calculated according to Chao \& Shen (2003), as follows:

$$
\mathrm{H}=\sum_{\mathrm{i}=1}^{\mathrm{s}}-\left(\mathrm{P}_{\mathrm{i}} \ln \mathrm{P}_{\mathrm{i}}\right)
$$

where $\mathrm{H}=$ the Shannon diversity index; $\mathrm{P}_{\mathrm{i}}=$ fraction of the entire population of species I; $\mathrm{S}=$ number of species; $\Sigma=$ sum from species 1 to $\mathrm{S}$.

To determine the carbon content stored in the microbial biomass, soil samples were collected two days before residue chopping (-2) and 2, 16, 30, 44, 58, 72 and 100 days after residue chopping. The soil samples collected from the 1-10 cm layer were placed in plastic bags, identified and transported ice-cooled to the laboratory. They were passed through a $2 \mathrm{~mm}$ sieve, and then a subsample was weighed and dried in a laboratory oven at $105{ }^{\circ} \mathrm{C}$ for $48 \mathrm{~h}$ to determine the soil moisture content. Six other subsamples of $4.0 \mathrm{~g}$ of moist soil were immediately placed in screw cap centrifuge tubes. Then the carbon content in the microbial biomass was determined by the IrradiationExtraction method, according to the methodology developed by Islam \& Weil (1998). The extract was filtered (quantitative filter paper) and a portion of $2 \mathrm{~mL}$ dried in a laboratory oven at $60^{\circ} \mathrm{C}$ for $4 \mathrm{~h}$ with $2 \mathrm{~mL}$ of $\mathrm{K}_{2} \mathrm{Cr}_{2} \mathrm{O}_{7} 1.25 \mathrm{~mol}_{\mathrm{c}} \mathrm{L}^{-1}+\mathrm{H}_{2} \mathrm{SO}_{4} 1 \mathrm{~mol} \mathrm{~L}^{-1}$. The carbon content was determined by colorimetric spectrophotometry at $580 \mathrm{~nm}$, using glucose solutions for calibration.

The results were subjected to analysis of variance ( $p>0.05)$, using SAS software (SAS, 1999), in an entirely randomized design and afterwards the simple linear regression equations (linear and quadratic) were tested separately for the periods of evaluation. The field study was based on a hierarchical scheme in which the treatments were nested in sampling times.

\section{RESULTS}

The results of residue decomposition (Figure 1) show that rye produced the greatest quantity of initial dry matter $\left(5,971 \mathrm{~kg} \mathrm{ha}^{-1}\right)$, followed by black oat $\left(4,758 \mathrm{~kg} \mathrm{ha}^{-1}\right)$ and common vetch $\left(3,849 \mathrm{~kg} \mathrm{ha}^{-1}\right)$. The amount of dry matter produced was similar to other values reported in literature. Bolliger et al. (2006) reported that in Brazil, black oat produces 2$11 \mathrm{t} \mathrm{ha}^{-1}$, rye $4-8$ and common vetch $3-5 \mathrm{t} \mathrm{ha}^{-1}$ of dry matter. The decomposition coefficient $(k)$ in the decomposition curve of common vetch (legume) was around 0.011 day $^{-1}$, while for the grasses (rye and black oat), the coefficient was between 0.007 and 0.008 . This fact confirms that phytomass of legumes is 
decomposed faster than of grasses, due to the differences in the $\mathrm{C} / \mathrm{N}$ ratio of these materials, as observed by Aita \& Giacomini (2003). The time required for the decomposition of $50 \%$ of the initial residue matter $\left(t_{50}\right)$ was 96,87 and 62 days for rye, black oat and common vetch, respectively. In addition, the estimate of time necessary for the decomposition of $95 \%$ of the initial matter $\left(\mathrm{t}_{95}\right)$ was 417,376 and 268 days for rye, black oat and common vetch, respectively. In a similar experiment, Gatiboni et al. (2009) found decomposition coefficients of 0.006 and 0.009 day $^{-1}$ and $t_{50}$ of 115 and 77 days for rye and black oat, respectively. Singh et al. (2007) found $t_{50}$ of 25 and $t_{95}$ of 107 for sesbania pea and $t_{50}$ of 270 and $t_{95}$ of 1169 for wheat straw.

Figure 2 shows that up to 54 days after cutting (DAC) the diversity of the fauna population, measured by the Shannon Index, was similar in the three cover crops. As of 70 DAC, the Shannon diversity index dropped significantly for the common vetch treatment. This may be confirmed by the results of relative frequency (Figure 3), which shows that in the rye treatment, the most frequent groups at the beginning of the evaluations were Coleoptera, Collembola, Acarina and Hymenoptera and that throughout the process of residue decomposition, the frequency of Hymenoptera and reduction of Coleoptera, Collembola and Acarina remained the same, contributing to the increase in diversity in this treatment. For the oat treatment, the most frequent groups at the beginning of the evaluations were Hymenoptera, Coleoptera and Collembola (Figure 3) and throughout the residue decomposition, there was a reduction in the frequency of Hymenoptera and Coleoptera, but an increase in the frequency of Collembola, thus characterizing reduction of diversity in relation to the rye treatment (Figure 2). In the common vetch treatment, the most frequent groups at the beginning of the experiment

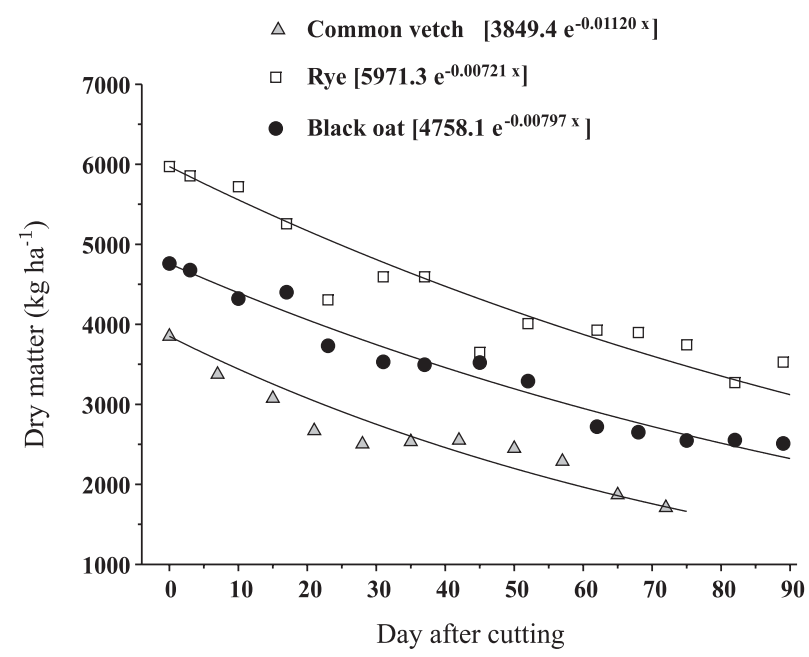

Figure 1. Dry matter of cover plant residues at different times during straw decomposition in no tillage system.

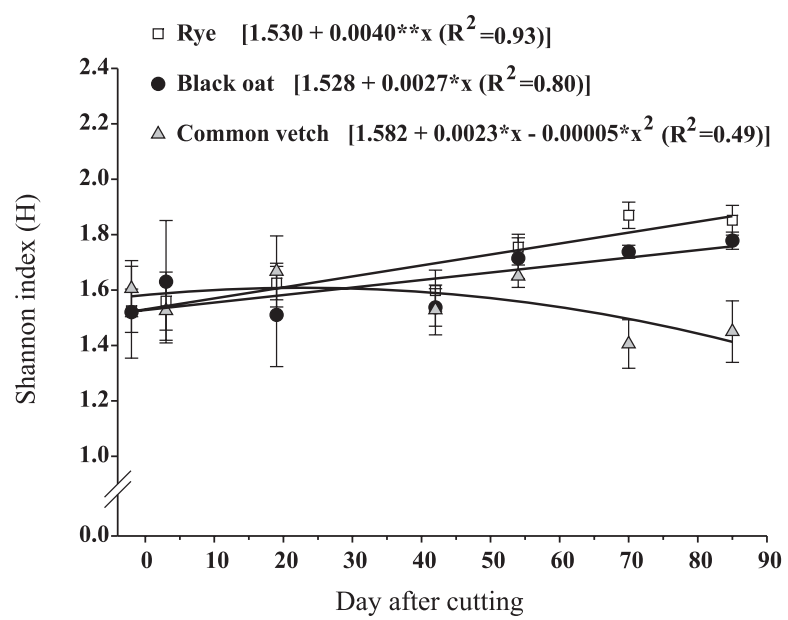

Figure 2. Shannon diversity index of soil fauna at different times during decomposition of cover plant residues in no tillage system. Error bars represent the standard error around each treatment mean.

were Collembola, Acarina, Hymenoptera and Coleoptera (Figure 3). At the end of the evaluation period, 85 DAC, the frequency of the Hymenoptera group remained the same, Coleoptera and Acarina decreased and Collembola increased, which resulted in a reduction in the diversity of the fauna population (Figure 2). In all treatments, an increase in the relative frequency of the Orthoptera group was observed in the last sampling.

The results obtained in this experiment show that the increase of the dominance of the Collembola group is associated with the decomposition rate of the residues, for among the treatments tested, rye straw was the most persistant residue on the soil surface (Figure 1), followed by oat and finally common vetch, which decomposed most rapidly. This was probably associated with the feeding habits of Collembola, for some species are typically fungivorous and find great food abundance in locations with residues in an advanced decomposition stage, due to the greater development of fungi in these situations (Wagner \& Wolf, 1998).

The amplitude of the $\mathrm{C}$ content stored in the soil microbial biomass $\left(\mathrm{C}_{\mathrm{SMB}}\right)$ varied from 90 to $230 \mathrm{mg} \mathrm{kg}^{-1} \mathrm{C}$ (Figure 4). The $\mathrm{C}_{\mathrm{SMB}}$ content in the soil was highest before residue chopping, so that there was a general behavior for all cover crops, of decrease in soil microbial biomass during the residue decomposition process. Seventeen days after residue chopping, a small increase in $\mathrm{C}_{\mathrm{SMB}}$ was observed, which may indicate a temporary increase of the microbial population in terms of the availability of easily decomposable compounds from the fresh straw, a phenomenon described by Fries (1997) and Wagner $\&$ Wolf (1998). The general trend of decrease in $\mathrm{C}_{\mathrm{SMB}}$ with advancing residue decomposition indicates a relation between the microbial population and the 


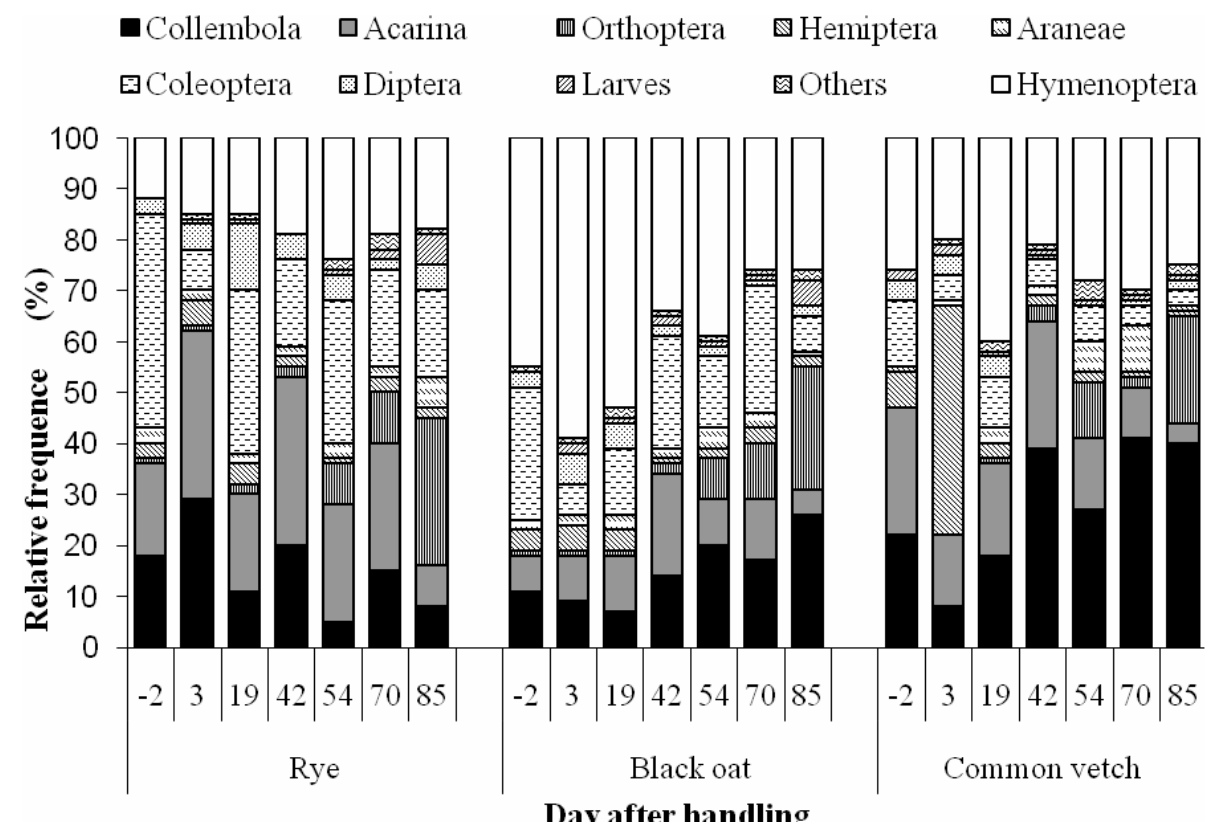

Figure 3. Relative frequency of main soil fauna groups at different times during decomposition of cover plant residues in no tillage system.

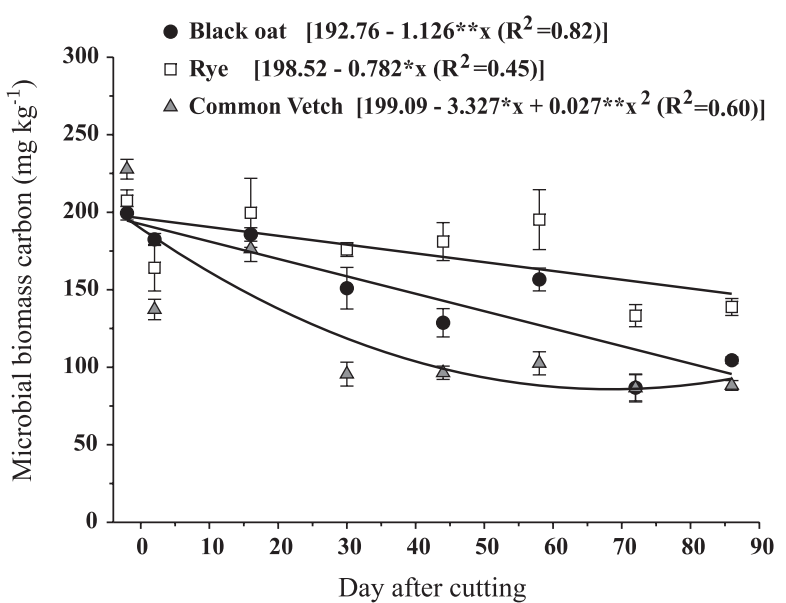

Figure 4. Carbon stored in soil microbial biomass at different times during decomposition of cover plant residues in no tillage system. Error bars represent the standard error around each treatment mean.

quantity of plant residues on the soil, with greater microbial activity when the straw is still in the initial phase of decomposition.

Regarding the differences among cover crops, it may be observed that the equations fit for the different crops have distinct behaviors (Figure 4): for rye, $\mathrm{C}_{\mathrm{SMB}}$ levels remained high in the initial phase of decomposition, and dropped in the final third of the evaluation period. For oat, the $\mathrm{C}_{\mathrm{SMB}}$ content was lower than for rye and dropped more quickly. For common vetch, the reduction in $\mathrm{C}_{\mathrm{SMB}}$ content was already intense at the beginning of the decomposition process, stabilizing at low values as of $30 \mathrm{DAC}$ of the cover crops (Figure 4). This behavior seems to be related to the presence of the crop residues on the soil.

\section{DISCUSSION}

Decomposition of organic matter is chiefly regulated by three interacting factors: the decomposer community, environmental conditions and residue quality. It is known that soil fauna positively influences decomposition rates and mobilizes nutrients from organic residues, but the contribution of the various soil fauna groups is still relatively unknown. It was concluded that the residue quality has a strong influence on the decomposer community, due to the differences observed between high $\mathrm{C} / \mathrm{N}$ ratio residues (black oat and rye) and a low $\mathrm{C} / \mathrm{N}$ ratio residue (common vetch). Until 54 days after cover crop cutting, the diversity of the fauna population, measured by the Shannon Index, was similar in the three cover crops. This shows that in the beginning of the decomposition process, the soil fauna diversity was maintained by the high straw quantity, maybe because a better soil cover permits survival of epigeic macrofauna, such as predatory arthopods (Lavelle et al., 1992), and in the later stages of straw decomposition, smaller saprophagous organisms (meso- and microfauna) are benefitted. This effect was confirmed by Fadini et al. (2001), who studied the soil fauna abundance and diversity in a grapevine orchard under different cover crops and without straw cover and commented that the soil cover, beneficial for growth, reproduction and refuge to animals, permitted a greater fauna diversity. In our experiment, after $70 \mathrm{DAC}$, the percentage of remaining 
straw differed among treatments; more than $60 \%$ of the initial straw quantity of the grasses was maintained, while legume had been reduced to less than $45 \%$ of the initial quantity (Figure 1). In this stage, the Shannon diversity index for the common vetch treatment was significantly lower, because the collembola population increased in this treatment (Figure 3), showing that with advancing decomposition, these organisms appear in the food web system.

These results are in agreement with Smith \& Bradford (2003), who found a higher population of macrofauna organisms in the first 30 days of straw decomposition, and after this period the decomposition was more related with smaller organisms (mesofauna and microfauna). The authors explained this difference by the general food habits of the fauna groups; the macrofauna, with some predators and high mobility, is able to control the mesofauna population by feeding on it. On the other hand, the less mobile mesofauna consumes more fragmented organic materials or is fungivorous (as some collembola species). For this reason, it was expected that mesofauna inhabits soils with plant residues in more advanced decomposition stages. This effect was shown by Lawrence \& Wise (2000), who excluded the aranae group from soil fauna and observed an increase in the Collembola group and increase in speed of residue decomposition. Gatiboni et al. (2009) found a decrease in soil fauna diversity during decomposition of black oat and rye straw whereas increased dominance of Collembola was detected in the later stages of straw decomposition, as also reported by Kladivko (2001). These studies support the results found in this experiment and show a change in the soil fauna groups in the different decomposition stages, principally due to the increase of Collembola in later stages of straw decomposition.

The results indicate that the $\mathrm{C}$ stored in the soil microbial biomass follows the average behavior of the residue quantity on the soil. Moreover, it is interesting to emphasize that the total straw quantity seems to affect the microbial biomass just as much as the $\mathrm{C} / \mathrm{N}$ ratio of the residues, since common vetch, in spite of the higher $\mathrm{N}$ content in its composition, was decomposed quickly and always sustained less microbial biomass than rye and oat residues. Thus, probably, the nutrition with $\mathrm{N}$ in the treatments with grasses has thus been based on the immobilization of native soil nitrogen.

The soil fauna apparently influenced the quantity and activity of microfauna, especially of fungi and bacteria. Soil animals may affect microbial communities directly, by feeding on various microorganisms, or indirectly, by mixing and channeling detritus, dispersing microbial propagules and excreting nutrient-rich wastes, suggesting that fauna - microbial interactions result in increased rates of soil nutrient mineralization (Bardgett \& Chan,
1999). Additionally, the low $\mathrm{C} / \mathrm{N}$ ratio in residue accelerates the residue decomposition, as stated by Smith \& Bradford (2003). In this experiment, the decomposition of legume residues, increase of colembolla populations (decrease in soil fauna diversity) and reduction of microbial activity (decrease in carbon content in soil microbial biomass) were observed concomitantly, showing that these factors are related during residue decomposition.

\section{CONCLUSIONS}

1. The decomposition rate of common vetch is higher than of rye and black oat residue.

2 . The $\mathrm{C}$ content stored in the microbial biomass decreased during the decomposition process of the cover crops, most rapidly in the treatment with common vetch.

3 . There is a reduction in the soil fauna diversity at the end of the decomposition process for the treatment with common vetch residue, mainly due to the increase in collembola populations.

\section{ACKNOWLEDGEMENTS}

The authors are indebted to the Empresa de Pesquisa Agropecuária e Extensão Rural de Santa Catarina - EPAGRI and the Universidade do Estado de Santa Catarina - UDESC, for funding this research and to the National Council for Scientific and Technological Development $(\mathrm{CNPq})$ for a grant to the first and second author.

\section{LITERATURE CITED}

AITA, C. \& GIACOMINI, S.J. Decomposição e liberação de nitrogênio dos resíduos culturais de plantas de cobertura solteiras e consorciadas. R. Bras. Ci. Solo, 27:601-612, 2003.

ANGHINONI, I. ,Fertilidade do solo e seu manejo em sistema plantio direto. In: NOVAIS, R.F.; ALVAREZ V., V.H.; BARROS, N.F.; FONTES, R.L.F.; CANTARUTTI, R.B. \& NEVES, J.C.L., eds. Fertilidade do solo. Viçosa, MG, Sociedade Brasileira de Ciência do Solo, 2007. p.873-928.

BARDGETT, R.D.; CHAN, K.F. Experimental evidence that soil fauna enhace nutrient mineralization and plant nutrient uptake in Montane grassland ecosystems. Soil Biol. Biochem., 31:1007-1014, 1999.

BOLLIGER, A.; MAGID, J.; AMADO, T.J.C.; SKORA NETO, F.; RIBEIRO, M.F.S.; CALEGARI, A.; RALISCH, R. \& NEERGAARD, A. Taking stock of the Brazilian "Zero-till revolution": A review of landmark research and farmers' practice. Adv. Agron., 91:1-64, 2006. 
BROOKES, P.C.; CAYUELA, M.L.; CONTIN, M.; DE NOBILI, M.; KEMMITT, S.J. \& MONDINI, C. The mineralization of fresh and humified soil organic matter by the soil microbial biomass. Waste Manag., 28:716-722, 2008.

CHAO, A. \& SHEN, T. Nonparametric estimation of Shannon's index of diversity when there are unseen species in sample. Environ. Ecol. Stat., 10:429-443, 2003.

DeBosz, K.; RASMUSSEN, P.H. \& PEDERSEN, A.R. Temporal variations in microbial biomass $\mathrm{C}$ and cellulolytic enzyme activity in arable soils: Effects of organic matter input. Applied Soil Ecol., 13:209-218, 1999.

EMPRESA BRASILEIRA DE PESQUISA AGROPECUÁRIA EMBRAPA. Centro Nacional de Pesquisa de Solos. Sistema brasileiro de classificação de solos. 2.ed. Rio de Janeiro, 2006. 306p.

FADINI, M.A.M.; REGINA, M.A.; FRÁGUAS, J.C. \& LOUZADA, J.N.C. Efeito da cobertura vegetal do solo sobre a abundância e diversidade de inimigos naturais de pragas em vinhedos. R. Bras. Frutic., 23:573-576, 2001.

FRIES, M.R. Microbiologia e matéria orgânica: Recuperação pelo sistema plantio direto. In: FRIES, M.R. \& DALMOLIN, R.S.D., eds. Atualização em recomendação de adubação e calagem. Ênfase em plantio direto. Santa Maria, Universidade Federal de Santa Maria, 1997. p.47-75.

GATIBONI, L.C.; COIMBRA, J.L.M.; WILDNER, L.P. \& DENARDIN, R.B.N. Modificações na fauna edáfica durante a decomposição da palhada em sistema plantio direto. Biotemas, 22:45-53, 2009.

HÄTTENSCHWILER, S.; TIUNOV, A.V. \& SCHEU, S Biodiversity and litter decomposition in terrestrial ecosystems. Ann. Rev. Ecol. Syst., 36:191-218, 2005.

ISLAM, K.R. \& WEIL, R.R. Microwave irradiation of soil for routine measurement of microbial biomass carbon. Biol. Fert. Soils, 27:408-416, 1998

KLADIVKO, E.J. Tillage systems and soil ecology. Soil Till. Res., 61:61-76, 2001.

LAVELLE, P. Faunal activities and soil processes: Adaptive strategies that determine ecosystem function. Adv. Ecol. Res., 27:93-132, 1997.

LAVELLE, P.; SPAIN, A.V.; BLANCHART, E.; MARTIN, A. \& MARTIN, S. Impact of soil fauna on the properties of soils in the humid tropics. In: LAL, R. \& SANCHES, P.A., eds. Myths and science of soils of the tropics. Madison, Soil Science Society of America, 1992. p.157-185.

LAWRENCE, K.L. \& WISE, D.H. Spider predation on forestfloor collembolan and evidence for indirect effects on decomposition. Pedobiologia, 44:33-39, 2000.
LUNDQUIST, E.J.; JACKSON, L.E.; SCOW, K.M. \& HSU, C. Changes in microbial biomass and community composition, and soil carbon and nitrogen pools after incorporation of rye into three California agricultural soils. Soil Biol. Biochem., 31:221-236, 1999.

MOÇO, M.K.S.; GAMA-RODRIGUES, E.F.; GAMARODRIGUES, A.C. \& CORREIA, M.E. Caracterização da fauna edáfica em diferentes coberturas vegetais na região norte fluminense. R. Bras. Ci. Solo, 29:555-564, 2005 .

MOREIRA, F.M.S. \& SIQUEIRA, J.O. Microbiologia e bioquímica do solo. 2.ed. Lavras, Universidade Federal de Lavras, 2006. 729p.

RASIAH, V. \& KAY, B.D. Temporal dynamics of microbial biomass and mineral-N in legume amended soils from a spatially variable landscape. Geoderma, 92:239-256, 1999.

RUTIGLIANO, F.A.; CASTALDI, S.; D’ASCOLI, R.; CARFORA, A.; MARZAIOLI, R. \& FIORETTO, A. Soil activities related to nitrogen cycle under three plant cover types in mediterranean environment. Appied Soil Ecol. 43:40-46, 2009 .

SAS Institute. Statistical Analysis System. User's guide: Statistics. Cary, 1999.

SEASTEDT, T.R. The role of microarthropods in decomposition and mineralization processes. Ann. Rev. Entomol., 29:2546, 1984.

SINGH, S.; GHOSHAL, N. \& SINGH, K.P. Variations in soil microbial biomass and crop roots due to differing resource quality inputs in a tropical dryland agroecosystem. Soil Biol. Biochem., 39:76-86, 2007.

SMITH, V.C. \& BRADFORD, M.A. Litter quality impacts on grassland litter decomposition are differently dependent on soil fauna across time. Applied Soil Ecol., 24:197-203, 2003.

STARK, C.H.; CONDRON, L.M. \& O'CALLAGHAN, M. Differences in soil enzyme activities, microbial community structure and short-term nitrogen mineralization resulting from farm management history and organic matter amendments. Soil Biol. Biochem., 40:1352-1363, 2008.

STINNER, B.R. \& HOUSE, G.J. Arthropods and other invertebrates in conservation-tillage agriculture. Ann. Rev. Entomol., 35:299-318, 1990.

WAGNER, G.H. \& WOLF, D.C. Carbon transformations and soil organic matter formation. In: SYLVIA, D.M.; FUHRMANN, J.J.; HARTEL, P.G. \& ZUBERER, D.A., eds. Principles and applications of soil microbiology. Englewood Cliffs, Prentice-Hall, 1998. p.218-258. 
